\title{
Questions and Questioning Techniques: A View of Indonesian Students' Preferences
}

\author{
Debora Tri Ragawanti \\ STiBA Satya Wacana, Kartini 15-17, Salatiga 50711, Middle Java, Indonesia \\ e-mail:dera03@yahoo.com
}

\begin{abstract}
This study investigated students' preference on teacher's questions and questionings techniques and more importantly on how they could facilitate or impede their learning. The results on teacher's questioning techniques showed that random nomination was more preferred than pre-arranged format nomination. In addition, techniques of nominating volunteering students and of giving wait-time were disliked by most student-respondents. As for types of question, the yes/no question was favored by most of the respondents. Different from the yes/no question, the number of respondents leaning forward to the analysis question, questions about fact of life, and questions to state opinion did not show a significant difference from the number of those leaning against the same questions.
\end{abstract}

Key words: question, questioning, preference

The most common type of classroom interaction, consists of initiation, response and feedback (Sinclair and Coulthard as quoted by $\mathrm{Ur}$ (1996), p. 227). In the initiation stage, questions are commonly raised to meet several pedagogical purposes such as to see if learners have acquired the imparted knowledge; to stimulate logical, reflective or imaginative thinking into issues being discussed; to direct attention to and to keep students involved in the lesson; to give space for self-expression; and to increase motivation and participation (Tsui, 1995, Ur, 1996, Richards \& Lockhart, 1996, \& Ralph, 1999). In delivering questions, teachers may use variety of techniques. The technique of asking questions is called questioning.

The role of question in the learning interaction process is believed to play important functions. Firstly, the quantity and the quality of questions affect the quantity and quality of student interaction in the lesson (Cullen, 1998, p. 180). Besides, it is considered helpful in scaffolding students' participation in classroom interaction (Hall, 2002, p. 99); and furthermore in language acquisition (Richards \& Lockhart, 1996, p. 185). 
There are two types of question: questions based on form and questions based on content. Questions based on form can be distinguished into convergent and divergent questions. Convergent questions generate one answer that is clearly right or wrong (Burden \& Byrd, 2003, p. 174). For example, questions that can be answered by 'yes' or 'no' and questions that have no possible alternative answers or interpretations (Gary, 2000, p. 22). These kinds of questions are believed to be helpful to develop auditory skills and vocabulary and to promote participation for the whole class before moving on to some other teaching methods (Richards \& Lockhart, 1996, p. 185). Unlike convergent questions, divergent questions always have more than one correct answer (Sadker \& Sadker, 1999, p. 107). These questions are also called open questions.

Questions based on Content consist of five types which basically are classified from low-level questions to high-level questions. Based on Bloom's taxonomy of questions the five types of questions are (pp. 111120), as follows:

a. Knowledge (memory) Questions

The first level of taxonomy is knowledge or memory question. This question requires students to identify or recollect information. The students just need to count on their memory to remember knowledge that they have learnt before, for example, "What is the capital of Indonesia?" "Who wrote Hamlet?"

b. Comprehension Questions

To answer this kind of question, the students are required not merely to recollect information but also to show their mastery of the material. Their mastery can be seen through their ability in reformulating and in illustrating the material in his or her words. For instance, instead of asking students, "What is the quotation?" the teacher can ask, "What do you think Hamlet means when he asks, 'To be or not to be: that is the question'?"

c. Analysis Questions

This kind of question is a higher order of question that requires students to think critically and comprehensively. To answer this type of question, students need to identify reasons, analyze available information or facts, and then arrive at conclusions, conjectures or generalizations (pp. 116-117). For example, to identify motives for 
the government to give severe punishment to Hester Prynne in Hawthorne's The Scarlet Letter, teachers can ask "How does the setting of the story tell you the reasons why the government gives such severe punishment?”

d. Synthesis Questions

Synthesis question is also a higher-order type of question that requires students to express their opinion to perform their imaginative and creative thinking. With this kind of question, students can use their imaginative and creative thinking to create imaginative communication, to make predictions, or to solve problems. This technique is believed to develop students' creative abilities (p. 118). For students to produce an imaginative communication, for example, teachers can ask a question like,'If you were a journalist, what questions would you ask to a very dangerous criminal?” To ask students to make predictions, teachers can ask," How would students react if attendance is not required?" As for problem solving, teachers can also give this activity: "You were in the situation of being stranded in a remote island. Choose three tools available in the sheet (consisting of various tools) and discuss with your group how you could escape from the island."

e. Evaluation Questions

Evaluation questions belong to a higher-order type of question. Similar to analysis and synthesis questions, this kind of question does not have one correct answer, either. To answer this kind of question, students are provided with sets of ideas, problems or situations. Then, they are asked to state their opinion to make a judgment on the ideas, problems or situations (pp. 119-120). The example of this question is "Why do you think people should or should not be allowed to do an abortion?”

A major goal for developing effective questioning techniques is to increase the amount of student participation (Jacobsen et al., 1999, p. 155). There are three teachers' techniques in questioning: Nominating Volunteering Students, Pre-Arranged Format and Random Nomination, and Wait-time/Waiting Time.

Nominating Volunteering Students is a technique to ask questions by calling for any volunteer to bid for the opportunity to answer the question. Hall (2002, p. 90) argues that this kind of question may help 
engage a number of students in the discussion in an efficient way. In terms of efficiency, Sizer in Sadker and Sadker (1999, p. 109) believes that this technique is efficient to make the teacher's lesson moves at a good pace and to make the main points of the lesson are covered.

However, Sadker (1999, p. 108) and Wilen (2001, p. 30) notice that there is a predisposition for teachers to nominate only students who want to be called on or who raise their hand. Therefore, only the more aggressive students who quickly volunteer continue being involved in the class discussion. However, the less aggressive students who tend to be less vocal will be drifted away from the class discussion. They often find themselves on the sidelines, unable, and unwilling to participate, whereas students learn more when they are actively participate in the class discussions (p. 30).

Pre-Arranged Format and Random Nomination is nominating students' names using pre-arranged format nomination and random nomination. The first technique can be done by calling on students' name sitting in the first row (this is based on the seat position). Then, the next selection goes to those sitting in the second row, etcetera. Another way is by calling on students' names based on the name order in the attendance list.

The second technique of nomination is selecting students' names at random. A motive underpinning this technique is that a prearranged format can produce boredom and troubling behavior for those who have already had their turn to answer the questions. For that reason, random selection is used to keep students' attention to teacher's questions as well as teacher' talk (Burden \& Byrd, 2003, p. 175).

Despite the usefulness of this random selection technique, Burden and Byrd demonstrate the shortcomings of this technique in practice. Teachers have an inclination to nominate more competent students than the less competent ones. Considering the pitfall, they suggest giving chances to all students to be successful in learning by answering the questions.

Wait-time/Waiting Time is a technique to facilitate students to answer teacher's question by giving wait-time, the amount of time teachers wait after asking a question until they intervene by prompting or redirecting the question to another student (Jacobsen et al., 1999, p. 163).

Theoretically speaking, wait-time is helpful for students. As what Sadker and Sadker (1999, pp. 127-128) observed, when teachers 
increased the wait time from one second or less into approximately three or five seconds or longer, students gave longer answers. Besides, the quality of students' responses improved and they showed more confidence in their answers. This can illustrate the positive influence of wait-time on the learning process and students' participation.

This paper is aimed at investigating students' preference on teacher's questions and questioning techniques and most importantly how they can facilitate or impede learning. The results of this study are expected to offer some insights about how a teacher's question and questioning technique affect students' learning process. Moreover, the results are expected to offer some strategies that can be used to scaffold students' learning.

\section{METHODS}

This study involved 117 students of English Department, Satya Wacana School of Foreign Languages, in Salatiga, Middle Java, Indonesia. They were randomly selected from different academic year levels ( $2^{\text {nd }}$ to $5^{\text {th }}$ year levels).

Instruments used to obtain data were questionnaire and interview. The use of questionnaire in this study was aimed at gathering statistical data and open responses about how types of question and techniques of questioning were preferred by the student-respondents.

The questions in the questionnaire consisted of closed-ended and open-ended questions. The closed-ended questions consisted of four statements of preferences designed using a four-point of Likert scale ranged from "I do not like it at all," "I do not like it very much," "I like it," and "I like it very much.” As for open-ended questions, the student respondents were asked to state their reasons of their choices in the closeended questions.

The interview involved thirty students and was administrated in the student-respondents' L1 (Bahasa Indonesia). This interview was conducted to pursue more detailed opinions and issues on students' thoughts and feelings about particular ways of teachers' questions and techniques of questioning.

The statistical data obtained from the closed-ended questionnaire was input into SPSS to obtain descriptive statistics of the overall data. By so doing, how many students preferred or inclined against certain items could be identified easily and the pattern of the students' answers could also be characterized easily. 


\section{FINDINGS AND DISCUSSION}

\section{Students’ Preference of Questioning Techniques}

This section explores students' standpoints on how they prefer to each technique of questioning and how teachers' questioning techniques can promote or impede students' learning.

\section{a. Students' preference on teachers' use of random nomination techniques and pre-arranged format}

Table 1 demonstrates that sixty-eight students liked the random nomination and thirteen students liked it very much. As for the prearranged format nomination, thirty-seven students stated that they liked it and only four of them liked it very much.

Table 1. Students' Preference on Teachers' Use of Pre-arranged Format and Random Nomination Techniques

\begin{tabular}{lcccc}
\hline $\begin{array}{c}\text { How do you like the way I don't like I Ion't like } \\
\text { your teachers ask } \\
\text { questions? }\end{array}$ & it at all & $\begin{array}{c}\text { I like it } \\
\text { it very } \\
\text { much }\end{array}$ & $\begin{array}{c}\text { I like it } \\
\text { very } \\
\text { much }\end{array}$ \\
\hline $\begin{array}{l}\text { call students' name based } \\
\text { on the seat position? }\end{array}$ & 17 & 59 & 37 & 4 \\
$\begin{array}{l}\text { (percentage) } \\
\text { call students' name }\end{array}$ & $14.5 \%$ & $50.4 \%$ & $31.6 \%$ & $3.4 \%$ \\
randomly & 8 & 25 & 68 & 13 \\
(percentage) & $7.0 \%$ & $21.9 \%$ & $59.6 \%$ & $11.4 \%$ \\
\hline
\end{tabular}

Students' preference on teachers' use of random nomination techniques

The quantitative results above show that the random nomination technique is preferred by most students. One of the reasons is that this technique is advantageous to keep students attentive. Accordingly, in every question addressed they put their efforts to prepare the answer as seen in this interview with a student below (all of the sources of data written in this article are the original utterances).

Choosing students randomly to answer their questions encourages all students to get ready to answer every question (Source of data: Interview with student 15). 
Aside from this advantage, the technique is likely to bring about several pitfalls. The following extracts illustrate how students feel about the disadvantage of this technique:

...there are times when teachers select the more competent students most of the time. That makes us feel inferior to take apart in answering teacher's question (Source of data: Interview with student 6).

We feel bad when we see that the teacher often addresses questions for us who apparently less competent but give less to those who are apparently more competent. We then think that we, the less competent students are given more question than the more competent ones (Source of data: Interview with student 27).

Student 6 found it unfair when the teacher invited the more able students to answer questions. By contrast, student 27 felt their teacher unjustly pointed the less competent students more than the more competent ones. The main point that can be made through these extracts is that there is a high possibility for teachers to select particular students to answer. Such unbalanced treatment can affect students' feeling to participate in answering the teacher's questions.

Such a problem may be close to what Richard and Lockhart (1994, p. 139) define as teachers' action zone, times when teachers invite particular students more than others. In this case, the vocal students nominated most of the time are within the teacher's action zone and they are likely to participate more. By contrast, students who seem less vocal would feel that they are not within the teacher's action zone. As a result, they possibly feel accounted out and participate less.

Students' preference on teachers' use of pre-arranged format

The idea of selecting students based on seat positions, however, seems to have less preference from the student-respondents. An argument for that can be seen as follows:

When teachers choose students based on their seat position the students will pay attention to questions that belong to their own turn (Source of data: Interview with student 15). 
Students' argument for their dislike is because students tend to prepare only for questions pointed to them. Although this technique seems not to elicit many voices from the student-respondents, its merits are worth to look at:

I prefer teachers calling on students' name based on the seat position. By so doing, we know that we have to answer certain questions so we have some time to think about the answer (Source of data: Interview with student 23).

Calling on students' name based on the seat position allows students to prepare for the answer so we will not get flustered when the teachers call on our name to answer (Source of data: Interview with student 12).

Appointing students based on their seat position can help students to have more time to generate their thinking process to think about the answer and to prepare themselves mentally for presenting the answer so that they can speak well when answering the question and do not become nervous or stumble.

\section{b. Students' preference on teachers' technique of nominating volunteering students}

As illustrated in Table 2, sixty-one students did not like their teachers to nominate volunteering students very much and seventeen of them did not like it at all. It means that $67.3 \%$ of the students showed dislike and $32.7 \%$ showed their liking of this technique.

Table 2. Students' Preference of the Technique of Asking for Volunteers to Provide Answers

\begin{tabular}{lcccc}
\hline $\begin{array}{c}\text { How do you like the } \\
\text { way your teachers ask } \\
\text { questions? }\end{array}$ & $\begin{array}{c}\text { I don't } \\
\text { like it at } \\
\text { all }\end{array}$ & $\begin{array}{c}\text { I don't } \\
\text { like it } \\
\text { very } \\
\text { much }\end{array}$ & I like it & $\begin{array}{c}\text { I like it } \\
\text { very } \\
\text { much }\end{array}$ \\
\hline $\begin{array}{l}\text { Ask for volunteer who } \\
\text { want to answer the }\end{array}$ & 17 & 61 & 31 & 7 \\
$\begin{array}{l}\text { question } \\
\text { (Percentage) }\end{array}$ & $14.7 \%$ & $52.6 \%$ & $26.7 \%$ & $6.0 \%$ \\
\hline
\end{tabular}


Below is the representation of ideas on what they thought and felt about this technique:

Asking for volunteers to answer questions works more for active students but not for the passive/quiet ones (Source of data: Interview with student 31).

If teachers appoint students who raise their hands only, there will be only certain students who would like to volunteer. Quiet students might also know the answers but in this case, they tend to be reluctant to participate because there have been several students who have already answered the question. Therefore, teachers should not only appoint to those who raise their hands only (Source of data: Interview with student 28).

Those students saw such a technique help best for articulate students but work less for the inarticulate ones. In the situation where many volunteers were participating, the less active or quiet students might feel reluctant to participate.

This picture is probably closest to phenomena described by Ted and Sizer in Sadker and Sadker (1999, p. 108). They see a tendency for teachers to nominate students who volunteer or who raise hands first. As a result, students, who want to talk, get chances to talk. Those who want to keep silent, stay silent. In this case, Ted \& Sizer further describe that when the teacher nominates students who like to volunteer, many students feel ignored. In this way, reticent students often feel unimportant and unwilling to participate.

Despite their reasons for disliking this technique, a motive for students to like their teachers to nominate volunteering students is meaningful to look into:

This technique gives opportunities to all students to participate. This is also good to motivate and stimulate students to think and to state their opinion (Source of data: Interview with student 25).

This opinion implicitly suggests a very good point of this technique. Ideally, this technique gives chances to all students to answer teachers' questions. In addition, it also can challenge students to think about the answer and try out their answer. 


\section{c. Students' preference on teachers' use of wait-time}

The last issue related to the strategy of questioning is waiting for a longer time for students to answer the question. Students show less preference for this option. As displayed in Table 3, eighty students expressed that they did not really like it and fourteen of them expressed that they did not like it at all.

\section{Table 3. Students’ Preference of Teachers' Use of Wait-time}

\begin{tabular}{lcccc}
\hline $\begin{array}{c}\text { How do you like the } \\
\text { way your teachers } \\
\text { ask questions? }\end{array}$ & $\begin{array}{c}\text { I don't } \\
\text { like it at } \\
\text { all }\end{array}$ & $\begin{array}{c}\text { I don't } \\
\text { like it } \\
\text { very } \\
\text { much }\end{array}$ & I like it & $\begin{array}{c}\text { I like it } \\
\text { very much }\end{array}$ \\
\hline $\begin{array}{l}\text { wait for a longer time } \\
\text { for students to answer } \\
\text { the question? }\end{array}$ & 14 & 80 & 18 & 5 \\
\begin{tabular}{l} 
(percentage) \\
\hline
\end{tabular} & $12.0 \%$ & $68.4 \%$ & $15.4 \%$ & $4.3 \%$ \\
\hline
\end{tabular}

The number of students who disfavored to this practice is $80.4 \%$. Reasons behind their options are stated as follows:

Waiting for a longer time for students to answer is good but may be the wait time is not too long. It can be too depressing for students who really do not know the answers (Source of data: Interview with student 3).

Giving a wait time is good but perhaps not too long because we have to answer another question (Source of data: Interview with student 2).

Do not wait too long for a student to answer because the other students who would like to answer will also wait to answer (Source of data: Interview with student 6).

The students above stated that they did not like the idea of giving a toolong-wait-time since it might not facilitate learning but give some psychological pressures to the student being asked and might change the atmosphere of the class. Therefore, they preferred a not-too-long-waittime for a student to answer questions due to the efficiency to the class activity and the psychological condition of the students themselves. Conversely, if the wait time is not too long they found it very supportive for them in the following ways: 
Wait time is helpful because it gives us time to think about the answer because some questions require us to do analysis so we need a longer time to think about the answer (Source of data: Interview with student 2).

When a teacher gives a question we are sometimes not ready yet. Besides, we as students have different capacity of thinking. Some of us can think fast, some others are slow. Wait time helps us to give more time to think about the answer so we can prepare the answer quite well (Source of data: Interview with student 12).

Wait-time, according to the students, facilitated them to understand the questions that required hard thinking and helped them prepare to present their answer. In addition, it helped best to accommodate students' different level of thinking, especially those who needed more time to think. This may go along with what Nunan \& Clarice (1996) believe that wait-time is helpful for students since it allows them a greater processing time to comprehend and interpret the teacher's questions.

\section{Students’ Preference of Types of Question}

Apart from teachers' questioning strategies, there is always the need to employ a variety of questions, such as yes/no questions, analysis question, questions about facts of life and questions that require students to state their opinion. The discussion in this part looks at how students prefer those types of question and to see how the questions can help or hinder them to take part in the classroom. Table 4 is the statistical result of students' preference on each type of question.

\section{a. Students' preference of yes/no questions}

As revealed in Table 4, sixty-six students showed their preference to yes/no question and 44 of them did not really like or did not like it at all. Several reasons underpinning the choice can be seen along these lines:

Yes/no question is easier to state than the other types of questions, just yes or no (Source of data: Interview with student 12).

The type of question that I like the most is yes/no question because it is very simple to express, just yes or no (Source of data: Interview with student 22). 
Table 4. Students' Preference of Types of Question

\begin{tabular}{|c|c|c|c|c|}
\hline $\begin{array}{l}\text { How do you like to } \\
\text { participate when your } \\
\text { teachers ask you }\end{array}$ & $\begin{array}{l}\text { I do not } \\
\text { like it }\end{array}$ & $\begin{array}{l}\text { I do not } \\
\text { like it very } \\
\text { much }\end{array}$ & $\begin{array}{l}\text { I like } \\
\text { it }\end{array}$ & $\begin{array}{l}\text { I like it } \\
\text { very } \\
\text { much }\end{array}$ \\
\hline Yes/no question & 7 & 37 & 47 & 19 \\
\hline (Percentage) & $6.4 \%$ & $33.6 \%$ & $42.7 \%$ & $17.3 \%$ \\
\hline $\begin{array}{l}\text { Questions that make you } \\
\text { analyze information (e.g. } \\
\text { analyzing characters in a } \\
\text { story, analyzing errors in } \\
\text { a sentence) }\end{array}$ & 8 & 48 & 47 & 14 \\
\hline (Percentage) & $6.8 \%$ & $41.0 \%$ & $40.2 \%$ & $12.0 \%$ \\
\hline $\begin{array}{l}\text { Questions about facts of } \\
\text { your life }\end{array}$ & 20 & 43 & 38 & 15 \\
\hline (Percentage) & $17.2 \%$ & $37.1 \%$ & $32.8 \%$ & $12.9 \%$ \\
\hline $\begin{array}{l}\text { Questions that make you } \\
\text { state your opinion }\end{array}$ & 5 & 44 & 41 & 27 \\
\hline (Percentage) & $4.3 \%$ & $37.6 \%$ & $35.0 \%$ & $23.1 \%$ \\
\hline
\end{tabular}

The idea of being simple and easier to state the answer seems to be the main reason why the students above liked yes/no question. As for the reason of objection, they did not like it since it did not require thoughtful thinking:

When I answer a yes/no question, I just need to answer yes or no, that's it. In terms of content, I see it too shallow. The answer also seems not need much of our understanding to answer the question (Source of data: Interview with student 11).

\section{b. Students' preference of analysis questions}

Sixty-one students leant toward questions that require students to analyze information and 56 of them leant against it. The reason why they disfavored this type of question is as follows:

I do not like a question that requires me to do an analysis because it is difficult. We need to answer it in detailed and it requires certain thinking pattern. For example, when we are asked to answer whether 
certain chunks of words are a sentence, we need to think such as what is a sentence. Then we try to analyze if the chunks of words are a sentence or not. This kind of question is to be the spook of questions (Source of data: Interview with students 11 and 12).

These students found this type of question was hard since it required much thoughtful thinking. It is not surprising then if these students compared it to a haunting danger, something frightening and something that could make them nervous.

Aside from that opinion, supportive opinion on this type of question is also necessarily to look at:

Analyzing texts like in reading course, for instance, allows us to think what certain words or sentences mean and process the tentative answers into our logical thinking on how those words can mean something and how other words can mean something else. By so doing it can facilitate us to get the answer and train us to think rapidly (Source of data: Interview with student 17).

Analyzing things such as analyzing a novel can help us dig out our understanding toward the content or the message of the novel. In short it helps develop our thinking process (Source of data: Interview with students and 15).

Those students argued that analysis questions had several strengths in assisting students to think more deeply and quickly. Additionally, such an analysis helps students to have deeper understanding of certain ideas which facilitate them to develop their thinking skill.

\section{c. Students' preference of questions related to the fact of life}

The result shows that sixty-three students leant against this type and fifty-three students leant forward this type. Several pro and contra opinions can be seen in the two extracts taken from the interview data below:

Mostly teachers ask questions about students' self experience. I do not like it because to some extent it has a tendency to dig up our personal matters of life (Source of data: Interview with student 15). I am more enthusiastic in answering questions related to my own experience because I have experienced it by myself (Source of data: Interview with student 7). 
Student 15 did not like the idea of answering questions related to facts of students' life if the questions were too personal. In contrast, student 7 liked such questions because it helped him/her know the subject matter being asked by relating it to his/her own experience, something that the student knew and experienced.

\section{d. Students' preference of questions that require students to state their opinion}

Toward types of questions that required them to state their opinion, sixty-eight students expressed their favorite to it, forty-four of them did not really like it and five of them did not like it at all. Several opinions conforming to the point are as follows:

Stating opinion helps me make progress by giving me more time to practice speaking English so I can speak English more fluently (Source of data: Interview with student 19).

Being able to state opinion gives me certain satisfactory because I am able to express what I want to express and I can get to know the teacher's' opinion about my answer. When the teacher says that my answer is correct I will be satisfied and remember the answer. Similarly, when my answer is not correct, I still get satisfactory through the input from the teacher. Moreover, the feedback can make me remember about the point that I have answered (Source of data: Interview with students 11, 16, and 23).

Stating opinion, according to the students, gives them a sense of satisfaction to be able to express their opinion. If the answer is correct, they feel a sense of achievement to be able to answer the question correctly. If their answer is wrong, they will get more understanding by comparing their original answer to their teacher's answer. Lastly, such a type of question can promote fluency in their speaking skill since they will use English to express their opinion.

\section{CONCLUSION}

Based on the results of the study presented above, there are several points worthy to put into consideration when we, teachers, raise questions and use questioning techniques in the classroom. 
In terms of questioning techniques, choosing pre-arranged format nomination psychologically can be helpful to allow some time for students to think about and to present the answers. However, students possibly keep attention only on their turn and not to all questions. Another technique of questioning, random nomination technique, can be helpful to make students attentive to all questions although it likely can produce the unbalanced distribution of questions to particular students only.

To avoid the unbalanced distribution, the technique of nominating volunteering students can be used since it gives opportunity to all students to answer/participate and can challenge students to think and to try out the answer. Nevertheless, we need to be careful as it has a tendency to engage the participation of more competent students. This tendency subsequently may cause the less competent students to feel missed out and do not try to participate. As for the last technique, waiting-time, it is helpful to provide more time to think and to prepare presenting the answer as long as it is not too long. Otherwise, it can give pressure to the students being asked.

As for the types of question, 'Yes' /'No' question can engage students' participation more easily since this type of question is easy to answer. However, it may fail to gain students' preference since its content tends to be trivial and does not require much knowledge to answer. As for analysis question, it can help students to develop their rapid and deeper thinking process toward the content of the lesson. Yet, this type of question may fail to gain students' participation since this is a tough and 'frightening' type of question which requires thoughtful thinking.

Questions that require students to state their opinion can promote participation since it gives them a sense of satisfaction and of achievement when their answer is correct. It also helps them compare their original answer to the correct one when their answer is wrong. Furthermore, it can foster speaking fluency. In relation to that type of question, questions that require students to state their opinion about facts of life are also viewed in this study. Such a question is preferred by most students since it allows them to answer what is close to their life or what they know and or they have experienced. Yet, it can fail to gain students' participation due to its potential weakness to reveal the students' personal matters. 


\section{REFERENCES}

Brown, J. D. (2001). Using surveys in language programs. Cambridge: Cambridge University Press.

Burden, P. R., \& Byrd, D. M. (2003). Methods for effective teaching (3rd ed.). Boston: Pearson Education.

Cullen, R. (1998). Teacher talk and the classroom context. ELT Journal, 52(3), 179-187.

Gary, B. (2000). Effective teaching methods ( $4^{\text {th }}$ ed.). New Jersey: Merril

Hall, J. K. (2002). Methods for teaching foreign languages. New Jersey: Merril Prentice Hall.

Jacobsen, D. A. et al. (1999). Methods for teaching (5th ed.). New Jersey: Prentice Hall.

Nunan, D., \& Clarice, L. (1996). The self-directed teacher: Managing the learning process. Cambridge: Cambridge University Press.

Ralph, E. G. (1999). Oral-questioning skills of novice teachers: ...Any questions? Journal of Instructional Psychology 26(4), 286-297.

Richards, J. C., \& Lockhart, C. (1996). Reflective teaching in second language classrooms. Cambridge: Cambridge University Press.

Sadker, M., \& Sadker, D. (1999). Questioning skills. In J. M. Cooper (Ed.), Classroom teaching skills. Boston: Houghton Mifflin.

Sinclair, J. Mc.H., \& Brazil, D. (1982). Teacher talk. Oxford: Oxford University Press.

Tsui, A. B. M. (1995). Introducing classroom interaction. London: Penguin.

Ur, P. (1996). A course in language teaching. Cambridge: Cambridge University Press.

Wilen, W. W. (2001). Exploring myths about teacher questioning in the social studies classroom. The Social Studies, 92(1), 23-26. 